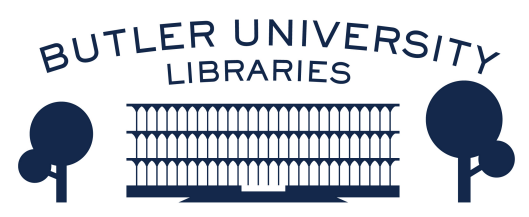

Journal of Hindu-Christian Studies

Volume 14

Article 6

January 2001

\title{
Hindu-Christian Dialogue: A Hindu Perspective
}

K. L. Seshagiri Rao

Follow this and additional works at: https://digitalcommons.butler.edu/jhcs

Part of the Religion Commons

\section{Recommended Citation}

Rao, K. L. Seshagiri (2001) "Hindu-Christian Dialogue: A Hindu Perspective," Journal of Hindu-Christian Studies: Vol. 14, Article 6.

Available at: https://doi.org/10.7825/2164-6279.1249

The Journal of Hindu-Christian Studies is a publication of the Society for Hindu-Christian Studies. The digital version is made available by Digital Commons @ Butler University. For questions about the Journal or the Society, please contact cbauman@butler.edu. For more information about Digital Commons @ Butler University, please contact digitalscholarship@butler.edu. 


\title{
Hindu-Christian Dialogue: A Hindu Perspective
}

\author{
K.L. Seshagiri Rao \\ University of South Carolina
}

I wish to express my deep appreciation and thanks to Professor Harold Coward for inviting me to contribute an article on Hindu-Christian Dialogue: A Hindu Perspective for his Bulletin. This theme has engaged my interest for the last three decades, and I am glad at the opportunity to express my thoughts on this very relevant and significant subject at the dawn of the 21st century.

There is no exact term for dharma in the English language. Neither the term Hinduism nor the word religion is adequate to translate sanatana dharma. Anyway, since nearly a billion people prefer to call themselves Hindus, and another two billion refer to them as Hindus, there is no point in arguing over the terminology. In this essay, therefore, I shall continue to use the terms Hindu and Hinduism. I shall communicate what Hinduism means to me, and how my involvement in Hindu-Christian dialogue has influenced my understanding of both the traditions.

I got my early lessons in Hinduism from my parents, who were devout Hindus. I was born seventy-two winters ago, and imbibed from my domestic and social environments aspects of Hindu tradition and practice. My first acquaintance with Christianity was in the late forties, when under the influence of Mahatma Gandhi, a number of students in Indian colleges took to the study of the Bible and the Gita. In my case, the study continued, and came to a focus when I accepted a fellowship from the Gandhi Peace Foundation, Delhi, to study Gandhi's religious thought. In that connection, I came into contact with and learned much from Hindu as well as Christian followers of Gandhi. I had also the opportunity to study, in some detail, other world religions. Further, as a doctoral student at Harvard University in the early sixties, I took a number of courses in Christian theology, history, and ethics; they have helped me to understand Christianity in the proper context.

I deeply cherish my tradition, but I do not wish it ever to be the only religion in the world. Nor do I see any need to turn a blind eye to its shortcomings. Actually, I am glad that there are other great religions which are, like mine, trying to stem the tides of violence, terrorism, war and materialism on one hand and trying to bring happiness and fulfilment through moral and spiritual instructions on the other.

\section{PAST}

In India, as in many Asian countries, Christianity came into effective contact with non-Christian traditions during the days of colonial expansion of Western powers: Portuguese, French, Danish and British. For Asian peoples, Christianity came mixed with and vitiated by imperialism, colonial domination, a degree of racism and a dose of Western culture. Even the architecture and music of the churches in the colonies imitated Western styles. These historical factors created difficulties for a proper appreciation of Christianity. During the period of struggle for Indian independence, I remember, the question was frequently raised: 'Why should Christianity be presented to the Hindus? Does the West desire to "dominate" Indian spirituality in the same way as it controls India's politics and economics?'

Christian missionaries used to make scathing attacks on Hinduism and dismiss it 
as a religion of superstition and crass idolatry, not to be taken seriously. They referred to the Hindus as polytheists, pagans and heathens. They implicitly believed that the Western nations possessed a superior religion and culture. Hence they went out to give and not to receive; their objective was to spread Christianity. The technique frequently adopted was to exaggerate the socalled vulnerable points in Hindu thought and practice with little appreciation of the positive elements in them. The works of philanthropy, social uplift; medical aid or educational services were often used as means for winning converts.

Hindu response to such criticisms was typical: praising one's own faith and blaming the faith of others are due to lack of sympathy and understanding. Each religion, like every geometric figure, has its own inherent logic and inner consistency. Unless one understands the inner logic, one cannot appreciate that religion. For example, Hindus worship one God (who is beyond names and forms) who makes Himself available to His devotees in many names and forms. From the time of the Rgveda (which says that: Truth is one, sages call it by many names) to Sri Ramakrishna and Mahatma Gandhi, the validity of many names and forms of the one God is asserted. In the absence of appreciation of this basic Hindu principle, criticisms such as the one above, miss the point altogether.

For all its hopes and opportunities, "Christian triumphalism" of the Colonial era did not succeed. Christianity continues to be, by and large, a minority religion in Asia; it has to live with and amidst a majority community of another faith. Western Christians do not fully realize the enormous cultural and national pressures faced by the Christian minorities in Asia. Asian Christians clearly see the practical situation and recognize that human community is religiously pluralistic. They see no signs of immediate or even distant displacement of all other religions by Christianity.

\section{PRESENT}

I know that in recent times, a number of
Christian thinkers and groups are trying hard to eliminate the burdens of the past, to redefine their attitudes to other cultures, religions and peoples, and to dissociate themselves from certain unhappy historical associations; however, Asian peoples are still handicapped in their appreciation of Christianity by what has been done to them in the past by Western nations.

Traditional theology, developed in religious isolation, has now become inadequate. Historically, Christianity, like every other world religion, is a particular religion; but it has a universal message. Each religion has to transcend itself to become universal. The Christian faith is challenged daily from within to enter into dialogue with the followers of other religions. "In My Father's house are many dwelling places. If this were not so, I would have told you" (John 14:2). Peter, the leader of the Apostles declares: "In truth, I see that God shows no partiality. Rather, in every nation whoever fears Him and acts uprightly is acceptable to him."'(Acts 10:34-5) There are scholars in recent decades, who have not felt shy of visiting other dwelling places in God's mansion. Thanks to the efforts of farseeing leaders like Paul Devanandan, Stanley Samartha, John Taylor, Dom Bede Griffiths; etc., the atmosphere is now much better. The World Council of Churches has struggled as a pioneer in the area of religions dialogue.

I have been involved in scores of important inter-religious conferences and Hindu-Christian dialogues organized by World Council of Churches, Temple of Understanding, World Conference of Religion and Peace, World Congress of Faith, etc. For example, I was invited as a Hindu guest to participate in the Fifth Assembly of The World Council of Churches in Nairobi in 1975. I was the cochairman of the International HinduChristian Consultation organized by WCC at Dehradun, India in 1981. I was a non-voting Hindu delegate to the World Conference on Mission and Evangelism convened by the WCC in San Antonio, Texas in 1989. By engaging in vigorous dialogue for the last 
three decades, the WCC has shown that Christian faith stands to gain by spreading the testimony of Christ to others and by receiving valuable insights from them. In my dialogue with Christians, I have understood much about Christianity, but also much about my own religious tradition.

It took some time for me to understand the diversity in Christian tradition. It certainly is difficult to make judgments on Christianity on the basis of a single sect or movement. Within Christianity, there are Catholics, Protestants, Followers of Eastern Orthodoxy, and within each branch, there are many denominations, not always harmonious with one another. In the late fifties, I once went into a Christian section of a South Indian village, in the course of my fieldwork. I met the members and their families. On inquiry, I came to know that they belonged to seven different Churches, and they scarcely knew about their Church histories. Some were Roman Catholics, but did not know where Rome was, some others were Anglicans, but did not know where England was, and so on. I wondered at that time what the European ecclesiastical struggles had to do with the communication of Jesus Christ to villagers in India. Thankfully, ecumenical dialogue is going on among these churches. As a Hindu, I pray. for the ecumenical unity of Christian churches. United Christianity is a spiritual gain to the world. It will also enable Christian activities to be coordinated for the benefit of humankind and of all creation.

I cherish my associations with enlightened Christian thinkers who have sought to realize that God is at work in events beyond the boundaries of the Christian church. God is already present in his world; we need only to recognize and respond to his presence. When Christ is exalted, whatever is universal in any religion is also exalted. I believe that Christ aimed at changing lives of persons, not their religious labels. In a multi-religious society, my dialogue with Christians has made me realize that there is need to recognize that God is one, religions are many. Creative theological formulations are needed to do justice to religious pluralism. Further, the spiritual traditions of the world have a great role to play in arresting the tides of violence, materialism, scepticism and scientism that is challenging all religions. In this sense, Christianity and Hinduism have to work together, not against one another, in humanizing humanity.

In my understanding of the New Testament, God's love embraces the whole world. Churches may be exclusivistic; Christ is universal. The Kingdom of God includes the entire humanity. The resemblances between Hindu and Christian parables and scriptural passages came as a pleasant surprise to me. Let me illustrate the point with the Song of Praise, in which Mary discloses to Elizabeth God's purpose:

For he who is mighty have done great things for me,

and holy is his name.

And his mercy is on those who fear him

from generation to generation.

He has scattered the proud in the imagination of their hearts, he has put down the mighty from their thrones, and exalted those of low degree; he has filled the hungry with good things,

and the rich he has sent empty away (Luke 1: 49-53).

Compare this with what Lord Krishna says about the purpose of avatar (incarnation of God on earth) in the Bhagavadgita:

When righteousness is weak and faints and unrighteousness exults in pride, then my Spirit arises on earth.

For the Salvation of those who are good, for the destruction of evil in men, for the fulfilment of the Kingdom of righteousness, I come into this world in the ages that pass

(Bh. G. IV. 7-8. tr. Juan Mascaro).

Incidentally, Hinduism and Christianity are the only world religions which reveal the 
doctrine of Incarnation though their interpretations of the doctrine are different.

\section{HINDU VIEW OF CHRIST}

Jesus Christ is an ineradicable part of modern Hinduism. The power of Cross is felt in the lives of many Hindus in different walks of life. Hindus adore Christ. The way in which Christ has touched their lives, and their responses to him are varied: some Hindus acknowledge Jesus as an avatar; some others consider him as a yogi, a satguru and so on. Mahatma Gandhi for instance, showed great reverence to Jesus Christ and publicly acknowledged his indebtedness to him, but refused to limit Jesus Christ to the boundaries of this or that church.

Hindus look upon Jesus without the appendages of theology, dogma or doctrine. They give attention to his life of love and forgiveness. In the majesty of pure living, in the breadth of his sympathy, in the unselfish and sacrificial outlook of his life, and in pure disinterested love, he was supreme. What strikes a Hindu above all is his complete obedience to the will of God; the more he emptied himself the more he discovered God. The Cross is not something to be believed in and subscribed to as a dogma; but something to be lived and borne in life and experience. Jesus signifies to the Hindus the transcendence of the ego as the whole purpose of morality and spirituality. The enlightened person gains release by the surrender of his little self and its vanities by the purity of self and devotion to God.

The New Testament symbol of the Kingdom of God made a powerful appeal to modern Hindu reformers. It showed them the Christian message in its moral aspect. The teachings of the Sermon on the Mount were not speculative; they were exemplified in the life of Christ. They were impressed that the "Kingdom of God" belongs to the humble and the poor, that the "persecuted and the meek" are its citizens; that the "pure in heart" see it, and that the "Kingdom" is not meat and drink, but "righteousness, and peace and joy in the Holy Spirit." On the social side, the Kingdom of God involved the establishment of right relationships between institutions and communities of people. Modern Hindu reformers felt that this aspect of Christ's teaching was much needed in India. They tried to inculcate that spirituality did not consist in turning away from poverty, misery, and ignorance, but in fully facing and fighting them.

I found that Gandhi's understanding and practice of the cross brought out fresh aspects of Jesus' life and character which the West had not so clearly perceived. He demonstrated how the soul force fights and overcomes evil only with the weapons of Truth and love. Although satyagraha was used by Gandhi, a Hindu against governments run by Christians (whether in South Africa or Britain), many Christians all over the world recognized that his movements were in truth Christian, a reviving and reinterpretation of the cross. Dr. Stanley Jones, the well-known American missionary (in his Gandhi: An Interpretation. P. 105) observes: "Never in human history has so much light been shed through this one man, and that man not even called Christian. Had not our Christianity been vitiated and overlain by our identification with unchristian attitudes and policies in public and private life, we would have seen at once the kinship between Gandhi's method and the cross."

Hindus do not accept the Bible as the only scripture and Jesus Christ as the only instance of God's self-disclosure. And yet the Hindus accept the Bible, and the scriptures of other religions along with the Vedas as God-given. Despite this theological difference between Hindu and Christian approaches, practical cooperation with one another is possible in overcoming violence, war, injustice, poverty and sickness in the world. In this regard, the following verses of the New Testament are very instructive:

"And John answered and said.' Master, we saw one cașting out devils in thy name; and we forbade him, because he followeth not with us. And Jesus said unto him, Forbid him not: for he that is 
not against us is for us." (Luke 9: 4$50)$.

May I say that Hindus are not against Jesus Christ; they love him and adore him. Further there are many devils to be cast out; Hindus and Christians should come together to vanquish them.

\section{HINDU APPROACH}

Hindus have expressed an ecumenical spirit in religious matters throughout history. Never have they claimed to be exclusive possessors of truth. It is not necessary to be or become a Hindu to obtain salvation. They recognize revealing and saving powers in all great religions. Hindus respect all prophets and sages who come to guide humanity. In the context of the diversity of human needs, they hold that the great religions of the world are not only relevant but also necessary. Hindus have shown willingness to learn from other traditions. They are at liberty to draw inspiration from any source in their spiritual quest. Actually, the Hindu tradition encourages its followers to celebrate each other's way of Godrealization. Reverence for other religions is an essential element of the Hindu spiritual vision.

Hinduism has witnessed the vicissitudes of history. It has periods of growth and stagnation which have brought many valuable and some questionable elements to life and society. New conditions bring new challenges to its adherents, while the age old shortcomings are still to be addressed. But it has also shown remarkable powers of revival. Saints and sages have continued to call the Hindus to reform themselves and their society by purging old abuses, by throwing out undesirable accretions, and by conserving valuable insights and practices. In this endeavour, Christian contacts and even criticism have been very helpful. Hindus have been resilient, open and have succeeded in several areas. For example, in my teenage days, it was inconceivable for people of different castes to eat together and work together, but now these prejudices have dissipated.
Hindus have never been an organized ecclesiastical body nor do they seek to convert humanity to any one set of beliefs. In this sense, they have never been and will never be in competition with Christianity or with any other religion. They have been generally accommodating and cooperative. The Hindu tradition has provided historical examples of this attitude. When Jews (after the second destruction of the Temple in Jerusalem by the Romans) and Zoroastrians (in the $7^{\text {th }}$ century when Persia was invaded by Muslims) sought shelter in India, they were received in their midst with warmth and understanding and were granted freedom of worship. The same spirit continues through the ages. Recently in 1961, India offered refuge to Dalai Lama and 100,000 of his followers from Tibet from the threat of the Chinese Communist army. For those who questioned the wisdom of this action. Dr. Radhakrishnan, the former President of India, said: "We cannot go against our own tradition and history."

Hindus point out that Yoga is not in competition with any religious tradition. Yogic meditative techniques have helped. spiritual aspirants across religious borders. They help a Hindu to become a better Hindu, a Christian a better Christian, and so forth. Men of other faiths have testified that their own dormant faith has come alive as consequence of yogi practices.

The Christian Church does not admit the theory of reincarnation, rebirth of a soul after death with a new body. In recent years, however, a number of Christian thinkers have considered reincarnation as a valid phenomenon, while at the same time, remaining firmly within the Christian faith. They also believe that it was acceptable in the Christian tradition in early times; and that it does justice to Christian God of love and compassion. An errant child is given enough opportunities to correct his mistakes; God wishes that no soul be lost. In Hinduism, spiritual liberation is obtained through many lifetimes. Each lifetime is a god-given opportunity for further spiritual progress.

The theory of reincarnation is closely 
related to the doctrine of Karma, that emphasizes the principle of moral causality. Not only does a person shall reap what he sows, but what he is reaping, is the result of what he has already sown. Man is the maker of his destiny. All sects and schools of Hinduism have realized the truth and value of this doctrine. The present day revival of the subject in philosophical, religious and popular circles in the West points to its importance. According to a recent Gallup poll survey, $23 \%$ of the North Americans and Europeans believe in reincarnation.

\section{FUTURE}

1. Historically, the dialogue of religions has broadened and deepened religious insights. Active dialogue and cooperation between Christianity and Hinduism will bring in greater light and deeper understanding.

2. Truth is many sided and our understanding of truth is fragmentary. Therefore, it is desirable, to go deep into one's own religious tradition and adhere firmly to it, while keeping an open mind regarding the Truth that may be available in other traditions.

3. Hindu-Christian dialogue has led to a stronger sense of the essential dignity of a human being as a human being. The caste system in India has considerably weakened. The integration of the 'untouchables' into the mainstream of Hindu Society, started by Gandhi; has recorded enormous success. Social obligations have assumed a greater importance.

4. In as much as God is one, the world is one and humanity is one, it is possible for Hindus and Christians to meet and cooperate at these vantage points and reinforce the religious life of humanity.

5. Hindu-Christian dialogue is necessary: i) to overcome misconceptions entertained about each others' tradition; ii) to achieve a clearer understanding of the similarities and differences between the two traditions; iii) and to promote spiritual and moral goods in them.

6. Hindu-Christian dialogue recognizes that i) religious indifference is bad, religious prejudice is worse; ii) proselytism is bad, conversion to a higher way of life is necessary; iii) that no religious tradition should present its message in a way that may lead to conflict and violence in societies. 